\title{
Leaf Physiological and Morphological Responses to Shade in Grass-Stage Seedlings and Young Trees of Longleaf Pine
}

\author{
Lisa J. Samuelson * and Tom A. Stokes \\ School of Forestry and Wildlife Sciences, Auburn University, Auburn, AL 36849, USA; \\ E-Mail: stoketa@auburn.edu \\ * Author to whom correspondence should be addressed; E-Mail: samuelj@auburn.edu; \\ Tel.: +1-334-844-1040; Fax: +1-334-844-1084.
}

Received: 14 June 2012; in revised form: 21 July 2012 / Accepted: 10 August 2012 /

Published: 20 August 2012

\begin{abstract}
Longleaf pine has been classified as very shade intolerant but leaf physiological plasticity to light is not well understood, especially given longleaf pine's persistent seedling grass stage. We examined leaf morphological and physiological responses to light in one-year-old grass-stage seedlings and young trees ranging in height from $4.6 \mathrm{~m}$ to $6.3 \mathrm{~m}$ to test the hypothesis that young longleaf pine would demonstrate leaf phenotypic plasticity to light environment. Seedlings were grown in a greenhouse under ambient levels of photosynthetically active radiation (PAR) or a $50 \%$ reduction in ambient PAR and whole branches of trees were shaded to provide a 50\% reduction in ambient PAR. In seedlings, shading reduced leaf mass per unit area (LMA), the light compensation point, and leaf dark respiration $\left(R_{D}\right)$, and increased the ratio of light-saturated photosynthesis to $R_{D}$ and chlorophyll $b$ and total chlorophyll expressed per unit leaf dry weight. In trees, shading reduced LMA, increased chlorophyll $a$, chlorophyll $b$ and total chlorophyll on a leaf dry weight basis, and increased allocation of total foliar nitrogen to chlorophyll nitrogen. Changes in leaf morphological and physiological traits indicate a degree of shade tolerance that may have implications for even and uneven-aged management of longleaf pine.
\end{abstract}

Keywords: Pinus palustris; shade tolerance; leaf mass per unit area; photosynthesis 


\section{Introduction}

Longleaf pine (Pinus palustris Mill.) is a conifer of the southeastern U.S. that once dominated the southern landscape, but because of land use changes, difficulties in seedling establishment, lack of fire and conversion to other southern pines, it now occupies $3 \%-5 \%$ of the original expanse $[1,2]$. The open-canopy structure of natural longleaf pine ecosystems is characterized by different age cohorts of longleaf pine in varying gap sizes within a mosaic of diffuse and direct light [3]. There is a renewed interest in restoring the longleaf pine ecosystem but successful establishment of longleaf pine is limited by an incomplete understanding of factors influencing juvenile growth [4]. Of the southern pines, longleaf pine is considered the most intolerant of competition [5]. However, field studies of shade tolerance in longleaf pine are often confounded by limitations in multiple resources. For example, Brockway and Outcalt [6] reported no relationship between light and longleaf pine seedling growth in gaps and speculated that root gaps were important in increasing available soil moisture and subsequent growth of seedlings. Rodriquez-Trejo et al. [7] observed that shade from adult longleaf pine trees had a nurse tree effect on longleaf pine seedlings along gap edges presumably by decreasing transpirational water losses and mortality from drought. In contrast, a strong positive relationship between light availability in gaps and seedling growth has been reported by McGuire et al. [8].

Longleaf pine may be moderately shade tolerant when young but become more intolerant of shade with increasing age or size [9]. Longleaf pine has a unique seedling grass stage in which internode elongation is suppressed, the terminal bud is protected from fire, and carbohydrate reserves in root systems accumulate to support a subsequent bolting stage of rapid stem elongation [10]. Even though longleaf pine has been classified as very shade intolerant based on its need for high light levels characteristic of clear cut and canopy gap environments [11-13], there are reports of grass stage durations in longleaf pine of 12 years and longer with partial shade [14]. Questions have been raised concerning the degree of shade tolerance in longleaf pine. For example, Bhuta et al. [9] examined historic growth responses of remnant longleaf pine stands to release events and concluded that longleaf pine seedlings may be less shade intolerant than formerly thought and seedlings can survive under heavy overstory competition awaiting release.

Successful establishment and early growth of longleaf pine in even and uneven-aged management systems would be enhanced by a better understanding of leaf plasticity to light environment [15]. Shade tolerance is an important consideration in determining plantation density, gap sizes and gap shapes. The objective of this research was to examine leaf morphological and physiological traits in grass-stage seedlings and young trees of longleaf pine under varying light availability to understand the ecological requirements in early growth stages. Seedlings were grown in pots and subjected to shade treatments in a greenhouse under optimal nutrient and water availability. Trees were approximately 15 years of age and considered young given that maturity is reached in 150 years and a lifespan of up to 300 years or more is possible in longleaf pine [16]. Leaf photosynthetic response to light, chlorophyll concentrations and leaf morphology were examined in seedlings and branches of trees exposed to $0 \%$ and $50 \%$ reductions in ambient PAR over one growing season. The $50 \%$ shade treatment was selected based on the mean annual canopy light transmittance of $30 \%$ to $80 \%$ observed in a canopy gap environment in longleaf pine forests [17]. We tested the hypothesis that artificially regenerated seedlings and young trees will exhibit phenotypic plasticity to light in leaf physiological 
and morphological traits. Specifically, that phenotypic plasticity to light would be expressed by changes in leaf traits that enhance energy capture and carbon gain in low light [18], such as reductions in the leaf mass per unit leaf area (LMA), dark respiration $\left(\mathrm{R}_{\mathrm{D}}\right)$, and the light compensation point (LCP) and by increases in the ratio of light-saturated assimilation $\left(\mathrm{A}_{\max }\right)$ to $\mathrm{R}_{\mathrm{D}}$, leaf apparent quantum yield $(\Phi)$, chlorophyll $a$, chlorophyll $b$ and total chlorophyll concentrations, and the percentage of total foliar nitrogen $(\mathrm{N})$ allocated to chlorophyll nitrogen $(\mathrm{N})$.

\section{Methods}

\subsection{Seedling Study}

In September 2009, one-year-old, nursery-grown container stock seedlings in the grass stage were planted in $6 \mathrm{~L}$ pots with a 65:20:15 mixture of peat, vermiculite and perlite along with micronutrients and placed outside in full sunlight and watered every other day to soil field capacity. Root collar diameters at planting were less than $1.0 \mathrm{~cm}$. Seedlings were from a mixed variety of sources across the Southeast (International Forest Company, Moultrie, GA, USA). Seedlings were watered every other day and fertilized every two to three weeks with a $400 \mathrm{ml}$ solution of 30:10:10 (N:P:K) per pot.

The seedling study was conducted in a climate-controlled greenhouse in which conditions were maintained close to ambient outside the greenhouse. Treatments were initiated 1 June 2010. The study was designed as a randomized block design with four blocks based on location in the greenhouse and two shade treatments and six seedlings in each treatment-block combination (48 seedlings total). Shade treatments consisted of a control treatment in which seedlings received ambient levels of photosynthetically active radiation (PAR) in the greenhouse or a $50 \%$ shade treatment in which ambient PAR in the greenhouse was reduced by $50 \%$. Shade chambers $(1.2 \mathrm{~mL} \times 0.5 \mathrm{mH} \times 0.5 \mathrm{~mW})$ were constructed out of $1.3 \mathrm{~cm}$ diameter polyvinyl chloride (PVC) pipe and covered with $50 \%$ shade cloth (Gempler's, Madison, WI, USA). During a sunny day under no cloud conditions on 1 August 2010, ambient PAR was monitored at 0830, 1200, and 1530 hours outside the greenhouse and within the greenhouse directly above the seedlings in both shade treatments using a quantum sensor (LI-190, LICOR Inc., Lincoln, NE, USA). Photosynthetically active radiation in an open area adjacent to the greenhouse ranged from 793 to $1533 \mu \mathrm{mol} \mathrm{m} \mathrm{m}^{-2}$ and ambient PAR in the greenhouse ranged from 441 to $1343 \mu \mathrm{mol} \mathrm{m} \mathrm{m}^{-2}$ (Figure 1). In the 50\% shade treatment, PAR ranged from 223 to $672 \mu \mathrm{mol} \mathrm{m} \mathrm{m}^{-2}$. Air temperature and relative humidity were measured at the same time as PAR using the portable gas exchange systems. Shade chambers decreased air temperature on average by $0.07{ }^{\circ} \mathrm{C}$ with no change in relative humidity. 
Figure 1. Mean photosynthetically active radiation (PAR) measured over one clear day under ambient conditions (a) outside and inside the greenhouse and under the 50\% shade treatment in the seedling study; and (b) outside and within the shade chambers in the tree study. For all means, the standard error was less than $12 \mu \mathrm{mol} \mathrm{m} \mathrm{s}^{-2}$.
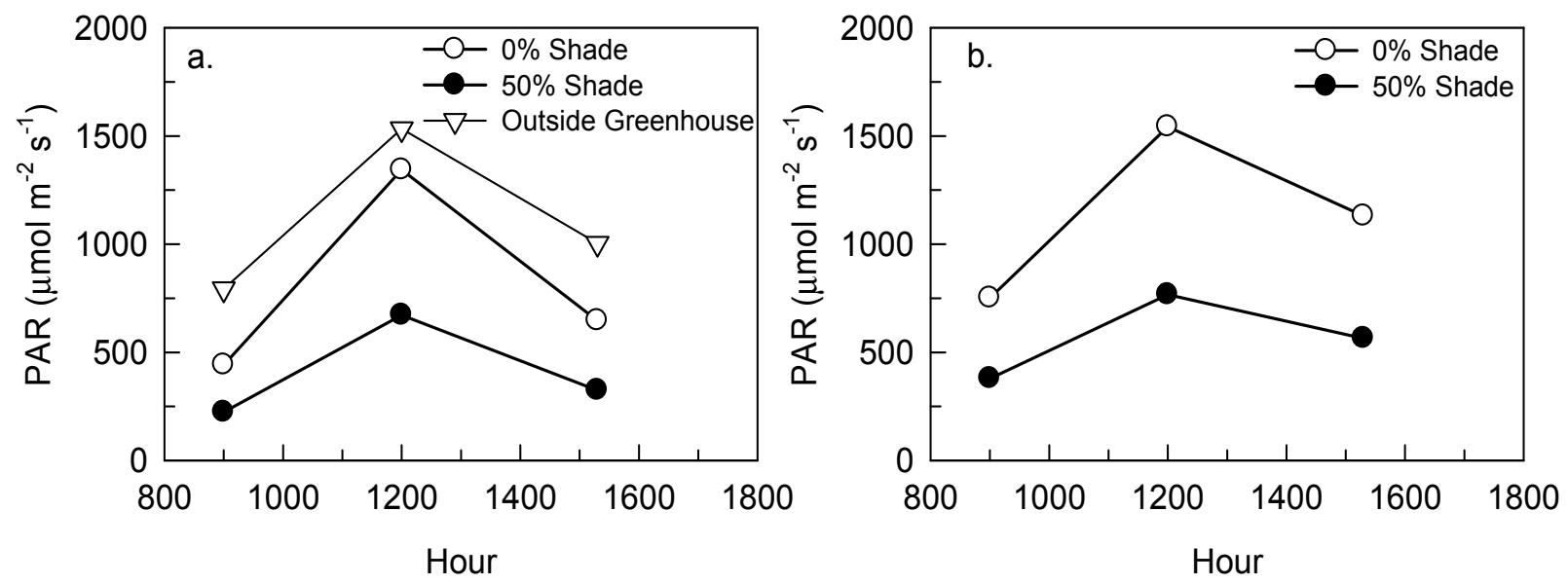

\subsection{Tree Study}

In designing the study, we assumed that tree branches were predominantly autonomous with respect to carbohydrate supply and that responses to shading would not be confounded by carbohydrate movement from sunlight branches into shaded branches. These assumptions were based on research by Cregg et al. [19] who reported no significant carbohydrate movement from branches of mature loblolly pine (Pinus taeda L.) in full sunlit to branches subjected to a $50 \%$ or $70 \%$ reduction in ambient PAR. Similarly, Henriksson [20] observed that shaded branches in downy birch (Betula pubescens Ehrh.) were autonomous. In young English walnut (Juglans regia L.) trees, carbon movement between branches subjected to shading treatments was only $1 \%$ of the diurnal net assimilation of a branch [21]. Branches have been found to be essentially autonomous with respect to water supply as well [22].

Five open-grown longleaf pine trees approximately 15-years-old and ranging in height from $4.6 \mathrm{~m}$ to $6.3 \mathrm{~m}$ (Table 1) planted on the campus of Auburn University within a 0.32 ha plot were selected for measurements. Individual tree crowns were open with no branch overlap within and among whorls and no crown overlap between trees. On 25 May 2010, one lower whorl was selected on each tree and a branch was randomly assigned to a $0 \%$ shade treatment (ambient PAR) or a 50\% shade treatment (50\% reduction in ambient PAR). Square shade chambers were constructed out of $1.3 \mathrm{~cm}$ diameter PVC pipe $(0.6 \mathrm{~m} \times 0.6 \mathrm{~m} \times 0.6 \mathrm{~m})$ and covered on all sides with $50 \%$ shade cloth (Gempler's, Madison, WI). Shade chambers were installed over entire branches and covered all existing foliage, which included two flushes from the previous year with room for shoot elongation due to new growth. Chambers were supported with legs and guy wires to allow flexibility and movement with wind. Stem diameter at breast height $(1.37 \mathrm{~m})$, total height, height to the whorl, diameter of the branch at the stem, and branch length at the beginning of the study are given in Table 1 . Trees were not irrigated. During a sunny day under no cloud conditions on 2 August 2010, PAR was measured above each control branch and within each shade chamber at 0830, 1200, and 1530 hours. At 1200 hours, PAR was 1542 and 766 
$\mu \mathrm{mol} \mathrm{m} \mathrm{m}^{-1}$ for the $0 \%$ and $50 \%$ shade treatment, respectively (Figure 1). During PAR measurements, shade chambers decreased air temperature on average by $0.6{ }^{\circ} \mathrm{C}$ and increased relative humidity by less than $1 \%$.

Table 1. Initial stem diameter at breast height (Dbh, $1.37 \mathrm{~m}$ ), total tree height, and for branches selected for shading treatments, height on the stem, branch diameter at the stem and branch length in the longleaf pine tree study. Measurements were taken prior to treatment initiation.

\begin{tabular}{|c|c|c|c|c|c|c|}
\hline Tree & Dbh (cm) & Height (m) & Shade & Branch height (m) & Branch diameter $(\mathrm{cm})$ & Branch length $(\mathrm{m})$ \\
\hline \multirow{2}{*}{1} & \multirow{2}{*}{7.0} & \multirow{2}{*}{5.2} & $0 \%$ & 0.58 & 1.85 & 0.63 \\
\hline & & & $50 \%$ & 0.58 & 1.77 & 0.66 \\
\hline \multirow{2}{*}{2} & \multirow{2}{*}{12.1} & \multirow{2}{*}{6.3} & $0 \%$ & 1.30 & 4.06 & 2.08 \\
\hline & & & $50 \%$ & 1.30 & 3.98 & 1.50 \\
\hline \multirow{2}{*}{3} & \multirow{2}{*}{10.0} & \multirow{2}{*}{6.3} & $0 \%$ & 1.42 & 3.12 & 1.09 \\
\hline & & & $50 \%$ & 1.15 & 2.39 & 1.11 \\
\hline \multirow{2}{*}{4} & \multirow{2}{*}{10.3} & \multirow{2}{*}{5.4} & $0 \%$ & 1.50 & 3.90 & 1.69 \\
\hline & & & $50 \%$ & 1.50 & 3.59 & 1.35 \\
\hline \multirow{2}{*}{5} & \multirow{2}{*}{5.5} & \multirow{2}{*}{4.6} & $0 \%$ & 1.48 & 1.45 & 0.27 \\
\hline & & & $50 \%$ & 1.49 & 1.51 & 0.29 \\
\hline
\end{tabular}

\subsection{Leaf Physiology and Morphology}

The response of net photosynthesis $\left(\mathrm{P}_{\text {net }}\right)$ to PAR was measured using portable open gas exchange systems equipped with a $\mathrm{CO}_{2}$ injector (LI-COR 6400; LI-COR Inc., Lincoln, NE, USA). Seedling gas exchange measurements were conducted on the first current year's flush, which was $95 \%$ developed, prior to treatment initiation, on 20-23 July 2010 and the second current year's flush, which developed fully under the treatments, on 24-27 August 2010 since the first flush was becoming shaded by the second flush. All seedlings were measured. Measurements on trees were conducted on one-year-old foliage (the second flush from the previous year) on 7 July 2010 and the first flush of growth of the current year on 18-19 August 2010. Seedlings were watered to full soil capacity the night before each measurement day. One attached fascicle was placed in a cuvette and light curves were initiated at a PAR of $2000 \mu \mathrm{mol} \mathrm{m}^{-2} \mathrm{~s}^{-1}$ followed by an eight-step reduction (2000, 1500, 1000, 500, 200, 100, 50, 20, $0 \mu \mathrm{mol} \mathrm{m} \mathrm{m}^{-2} \mathrm{~s}^{-1}$ ). Measurements were made at ambient temperature and ambient vapor pressure deficit and a set cuvette $\mathrm{CO}_{2}$ concentration of $400 \mathrm{ppm}$. Foliage was allowed to equilibrate for a minimum of five minutes at each light level. Light-saturated assimilation and stomatal conductance $\left(\mathrm{g}_{\mathrm{smax}}\right), \mathrm{R}_{\mathrm{D}}$, the LCP, and $\Phi$ were derived from the light response curves [23]. Gas exchange rates were corrected for total leaf surface area inside the cuvette [24]. All measurements were conducted by block with random selection of block and treatment order within a block. Two portable gas exchange systems were used with a machine measuring each shade treatment within a block simultaneously. One block a day was measured in the seedling study and two to three trees were measured a day in the tree study. Measurements were conducted on consecutive days and all days were clear during measurements. Gas exchange measurements were conducted between the hours of 0900 and 1400 . Predawn $\left(\Psi_{\mathrm{PD}}\right)$ (at 0500 hours) and midday ( $\left.\Psi_{\mathrm{MD}}\right)$ (at 1200 hours) leaf water potentials were measured 
on adjacent needles of the same age during each seedling and tree measurement session with a pressure chamber (PMS, Instrument Corp., Corvallis, OR, USA).

Leaf mass per unit area (LMA) was measured on the fascicles used in gas exchange measurement sessions. Needle lengths and fascicle diameters were measured and total fascicle area calculated following Samuelson et al. [24]. Fascicles were oven-dried to a constant mass at $70{ }^{\circ} \mathrm{C}$ and LMA was calculated as the ratio of needle dry mass to total needle surface area.

\subsection{Chlorophyll}

In September 2010, 10 fascicles from the current year's second flush in all seedlings and current year's first flush in all tree branches were collected for chlorophyll measurements. Chlorophyll extraction procedures followed Minocha et al. [25]. Seedling foliage was collected on 20-22 September and tree foliage on 26-28 September 2010. Needles were chopped into 3-4 mm segments in the dark and stored in the dark in a freezer at $-20{ }^{\circ} \mathrm{C}$ for 48 hours. Needle segments were then allowed to thaw in the dark and $0.2 \mathrm{~g}$ of material was placed in glass scintillation vials with $20 \mathrm{~mL}$ of $95 \%$ ethanol. Scintillation vials were placed in a water bath at $65{ }^{\circ} \mathrm{C}$ for 16 hours. After 16 hours, vials were cooled to room temperature and samples were vortexed at slow speed for $1 \mathrm{~min}$ then centrifuged for $5 \mathrm{~min}$ at $13,500 \mathrm{~g}$ and filtered. Absorbance of the samples was recorded at $649 \mathrm{~nm}$ and $664 \mathrm{~nm}$ with a spectrophotometer (Milton Roy Spectronic 1201, Milton Roy Analytical Products Division, Rochester, NY, USA). Chlorophyll $a$ and $b\left(\mu \mathrm{g} \mathrm{mL}^{-1}\right)$ were determined following Lichtenthaler [26]. Ten additional needles were collected from each seedling for measurement of relative water content which was used to calculated chlorophyll concentrations.

To determine if shading influenced the amount of foliar nitrogen $(\mathrm{N})$ allocated to chlorophyll N, N concentration was measured on foliage samples using an EA Flash 1112 analyzer (ThermoFinnigan, Milan, Italy). Foliage samples were dried at $70{ }^{\circ} \mathrm{C}$, and then finely ground using a ball mill to a $0.2 \mathrm{~mm}$ particle size. Ten percent of all of the samples were duplicated to check the instrument's precision. One NBS standard and one CE Elantech Inc. (Lakewood, NJ, USA) certified standard were used in each sample set to check the accuracy of the sample values. Sample sets were rerun if the coefficient of variation exceeded 5\%. Chlorophyll $\mathrm{N}$ content was calculated as $6.25 \%$ of total chlorophyll [27]. Foliar $\mathrm{N}$ was expressed on a leaf dry weight $\left(\mathrm{N}_{\mathrm{W}}\right)$ and leaf area $\left(\mathrm{N}_{\mathrm{A}}\right)$ basis.

\subsection{Data Analysis}

Differences between seedlings and trees were not tested due to different growth environments (greenhouse versus field, shading of entire seedlings versus branches) and greater nutrient and water availability in the seedling study. Light response curve data were fit to the model by Hanson et al. [23] using a modified Gauss-Newton non-linear iterative method until model convergence (SAS version 9.2; SAS Institute Inc., Cary, NC). The model was:

$$
\mathrm{Y}=\beta_{1}\left[1-\left(\left(1-\beta_{3} / \beta_{1}\right)^{(1-\mathrm{I} / \mathrm{\beta} 2)}\right)\right]
$$

where $Y$ is $P_{n e t} ; \beta_{1}$ is $A_{\max }$ at light saturation; $\beta_{2}$ is the LCP; $\beta_{3}$ is $R_{D}$ at zero irradiance; and $I$ is irradiance; Leaf $\mathrm{g}_{\mathrm{smax}}$ was calculated using the same model. Quantum yield was calculated from: 


$$
\Phi=\left[\left(\mathrm{A}_{\max } / \mathrm{LCP}\right) \times\left(1-\mathrm{R}_{\mathrm{D}} / \mathrm{A}_{\max }\right) \times \log \left(1-\mathrm{R}_{\mathrm{D}} / \mathrm{A}_{\max }\right)\right]
$$

Data were averaged by date of measurement (foliage age), block or tree, and shade treatment. All six seedlings in a block $\mathrm{x}$ treatment combination were measured for all variables and the average of the six seedlings represented the experimental unit. Shade effects on all variables were tested using randomized block design and analysis of variance (ANOVA). All statistical analyses were conducted using SAS statistical software (SAS version 9.2; SAS Institute Inc., Cary, NC, USA). Treatment effects were considered significant at $\alpha=0.10$. Given the exploratory context of the research a more liberal decision criterion was selected.

\section{Results}

\subsection{Seedlings}

The $50 \%$ shade treatment reduced LMA from 52 to $44 \mathrm{~g} \mathrm{~m}^{-2}$ in July and from 50 to $38 \mathrm{~g} \mathrm{~m}^{-2}$ in August (Table 2). Photosynthetic response to PAR in the $0 \%$ and $50 \%$ shade treatments followed the non-linear pattern described by Hanson et al. [23] (Figure 2).

Figure 2. Mean $( \pm \mathrm{SE})$ response of net photosynthesis $\left(\mathrm{P}_{\text {net }}\right)$ to photosynthetically active radiation (PAR) and shading treatment in longleaf pine seedlings measured in July (a) and August (b) and young trees measured in July (c) and August (d). For seedlings, needles measured in July were the current year's first flush and needles measured in August were the current year's second flush. For trees, needles measured in July were one-year-old foliage and needles measured in August were the current year's first flush.
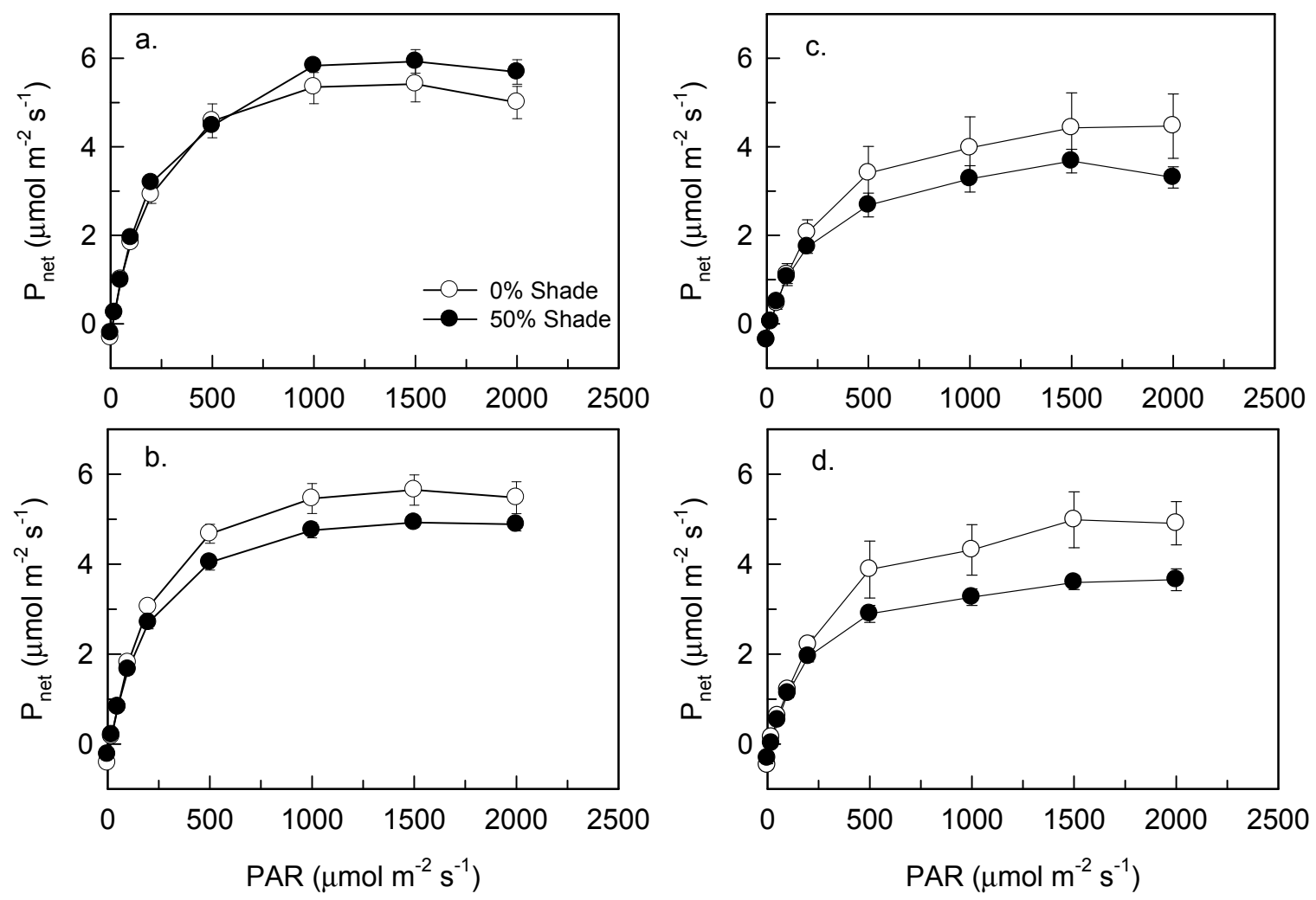
Table 2. Mean ( \pm SE) leaf mass per unit area (LMA), light-saturated net photosynthesis $\left(\mathrm{A}_{\max }\right)$ and stomatal conductance $\left(\mathrm{g}_{\mathrm{smax}}\right)$, and predawn $\left(\Psi_{\mathrm{PD}}\right)$ and midday $\left(\Psi_{\mathrm{MD}}\right)$ leaf water potential in response to shade treatment in longleaf pine seedlings $(\mathrm{S})$ and young trees $(\mathrm{T})$. For seedlings, needles measured in July were the current year's first flush and needles measured in August were the current year's second flush. For trees, needles measured in July were one-year-old foliage and needles measured in August were the current year's first flush.

\begin{tabular}{|c|c|c|c|c|c|c|c|}
\hline Age & Month & Shade & LMA $\left(\mathrm{g} \mathrm{m}^{-2}\right)$ & $\begin{array}{c}\mathbf{A}_{\max } \\
\left(\mu \mathrm{mol} \mathrm{m^{-2 }} \mathrm{s}^{-1}\right)\end{array}$ & $\begin{array}{c}\mathrm{g}_{\mathrm{smax}} \\
\left(\mathrm{mmol} \mathrm{\textrm {m } ^ { - 2 }} \mathrm{s}^{-1}\right)\end{array}$ & $\Psi_{\mathrm{PD}}(\mathrm{MPa})$ & $\Psi_{M D}(\mathrm{MPa})$ \\
\hline \multirow{6}{*}{$\mathrm{S}$} & \multirow{3}{*}{ Jul. } & $0 \%$ & $52.2 \pm 1.1$ & $5.1 \pm 0.2$ & $31.2 \pm 1.3$ & $-0.71 \pm 0.03$ & $-0.99 \pm 0.05$ \\
\hline & & $50 \%$ & $43.6 \pm 0.6$ & $5.8 \pm 0.4$ & $36.9 \pm 3.2$ & $-0.73 \pm 0.08$ & $-0.92 \pm 0.06$ \\
\hline & & $P>F$ & 0.007 & 0.140 & 0.120 & 0.859 & 0.149 \\
\hline & \multirow{3}{*}{ Aug. } & $0 \%$ & $49.9 \pm 0.9$ & $5.4 \pm 0.4$ & $34.2 \pm 3.7$ & $-0.72 \pm 0.02$ & $-0.90 \pm 0.04$ \\
\hline & & $50 \%$ & $38.5 \pm 1.6$ & $4.6 \pm 0.2$ & $34.1 \pm 1.5$ & $-0.69 \pm 0.04$ & $-0.78 \pm 0.08$ \\
\hline & & $P>F$ & 0.001 & 0.259 & 0.993 & 0.209 & 0.154 \\
\hline \multirow{6}{*}{$\mathrm{T}$} & \multirow{3}{*}{ Jul. } & $0 \%$ & $80.2 \pm 5.9$ & $4.4 \pm 0.8$ & $44.4 \pm 3.7$ & $-1.72 \pm 0.09$ & $-1.80 \pm 0.06$ \\
\hline & & $50 \%$ & $77.6 \pm 4.7$ & $3.3 \pm 0.3$ & $32.1 \pm 5.4$ & $-1.76 \pm 0.12$ & $-1.54 \pm 0.16$ \\
\hline & & $P>F$ & 0.583 & 0.172 & 0.147 & 0.456 & 0.213 \\
\hline & \multirow{3}{*}{ Aug. } & $0 \%$ & $74.5 \pm 3.7$ & $4.9 \pm 0.6$ & $49.7 \pm 9.4$ & $-1.34 \pm 0.09$ & $-1.78 \pm 0.14$ \\
\hline & & $50 \%$ & $64.4 \pm 3.7$ & $3.5 \pm 0.2$ & $27.8 \pm 1.8$ & $-1.18 \pm 0.14$ & $-1.35 \pm 0.04$ \\
\hline & & $P>F$ & $<0.001$ & 0.126 & 0.074 & 0.099 & 0.002 \\
\hline
\end{tabular}

In July and August, the light saturation point, defined as PAR at $95 \%$ of $A_{\max }$ [28], was approximately $700 \mu \mathrm{mol} \mathrm{m} \mathrm{m}^{-2} \mathrm{~s}^{-1}$ in the $0 \%$ and $50 \%$ shade treatments. No significant effect of shade treatment on $A_{\max }$ was observed any month and $A_{\max }$ was on average $5.2 \mu \mathrm{mol} \mathrm{m}{ }^{-2} \mathrm{~s}^{-1}$ (Table 2). Shading had no effect on $g_{\text {smax }}$ and average $g_{\text {smax }}$ was $34 \mathrm{mmol} \mathrm{m}^{-2} \mathrm{~s}^{-1}$ (Table 2). In August, 50\% shade decreased $R_{D}$ and increased the $A_{\max }: R_{D}$ ratio (Table 3 ). The LCP was unaffected by shading in July but in August 50\% shade reduced the LCP (Table 3). Shading reduced $\Phi$ in August (Table 3). No effect of shading treatment was detected for $\Psi_{\mathrm{PD}}$ and $\Psi_{\mathrm{MD}}$. Mean $\Psi_{\mathrm{PD}}$ ranged from $-0.69 \mathrm{MPa}$ to $-0.73 \mathrm{MPa}$ and $\Psi_{\mathrm{MD}}$ ranged from $-0.78 \mathrm{MPa}$ to $-0.99 \mathrm{MPa}$.

Foliar $\mathrm{N}_{\mathrm{W}}$ was similar between treatments and on average $25.9 \mathrm{mg} \mathrm{g}^{-1}$. Foliar $\mathrm{N}_{\mathrm{A}}$ was reduced by the $50 \%$ shade treatment (Table 4). No effects of shading were detected for chlorophyll $a$ but shading increased chlorophyll $b$ and total chlorophyll when expressed on a leaf dry weight basis (Table 5). Shading had no significant effect on the chlorophyll $a / b$ ratio and percentage of total $\mathrm{N}$ allocated to chlorophyll N. 
Table 3. Mean $( \pm \mathrm{SE})$ leaf dark respiration $\left(\mathrm{R}_{\mathrm{D}}\right)$, the ratio of light-saturated photosynthesis $\left(\mathrm{A}_{\max }\right)$ to $\mathrm{R}_{\mathrm{D}}$, apparent quantum yield $(\Phi)$ and the light compensation point (LCP) in response to shade treatment in longleaf pine seedlings (S) and young trees (T). For seedlings, needles measured in July were the current year's first flush and needles measured in August were the current year's second flush. For trees, needles measured in July were one-year-old foliage and needles measured in August were the current year's first flush.

\begin{tabular}{|c|c|c|c|c|c|c|}
\hline Age & Month & Shade & $R_{D}\left(\mu \mathrm{mol} \mathrm{m}{ }^{-2} s^{-1}\right)$ & $A_{\max }: R_{D}$ & $\begin{array}{c}\Phi\left(\mu \mathrm{mol} \mathrm{CO}_{2} \mu \mathrm{mol}\right. \\
\left.\text { photon }^{-1}\right)\end{array}$ & 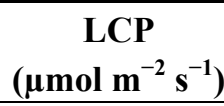 \\
\hline \multirow{6}{*}{$\mathrm{S}$} & \multirow{3}{*}{ Jul. } & $0 \%$ & $0.22 \pm 0.02$ & $31.4 \pm 3.5$ & $0.026 \pm 0.001$ & $8.5 \pm 0.8$ \\
\hline & & $50 \%$ & $0.18 \pm 0.02$ & $34.6 \pm 6.6$ & $0.025 \pm 0.001$ & $7.4 \pm 0.8$ \\
\hline & & $P>F$ & 0.422 & 0.763 & 0.696 & 0.492 \\
\hline & \multirow{3}{*}{ Aug. } & $0 \%$ & $0.32 \pm 0.01$ & $19.0 \pm 1.9$ & $0.025 \pm 0.001$ & $13.1 \pm 0.4$ \\
\hline & & $50 \%$ & $0.19 \pm 0.02$ & $34.0 \pm 3.2$ & $0.022 \pm 0.002$ & $8.9 \pm 0.7$ \\
\hline & & $P>F$ & 0.001 & 0.002 & 0.073 & 0.005 \\
\hline \multirow{6}{*}{$\mathrm{T}$} & \multirow{3}{*}{ Jul. } & $0 \%$ & $0.29 \pm 0.05$ & $16.8 \pm 3.4$ & $0.016 \pm 0.002$ & $19.6 \pm 4.2$ \\
\hline & & $50 \%$ & $0.24 \pm 0.04$ & $14.8 \pm 1.9$ & $0.015 \pm 0.002$ & $16.9 \pm 1.3$ \\
\hline & & $P>F$ & 0.568 & 0.704 & 0.288 & 0.577 \\
\hline & \multirow{3}{*}{ Aug. } & $0 \%$ & $0.27 \pm 0.04$ & $19.8 \pm 3.2$ & $0.017 \pm 0.003$ & $17.2 \pm 3.2$ \\
\hline & & $50 \%$ & $0.34 \pm 0.07$ & $12.8 \pm 3.4$ & $0.025 \pm 0.008$ & $18.0 \pm 4.2$ \\
\hline & & $P>F$ & 0.310 & 0.148 & 0.470 & 0.912 \\
\hline
\end{tabular}

Table 4. Mean ( \pm SE) foliar nitrogen expressed on a leaf area $\left(\mathrm{N}_{\mathrm{A}}\right)$ and leaf dry weight $\left(\mathrm{N}_{\mathrm{W}}\right)$ basis measured in September 2010 in response to shade treatment in longleaf pine seedlings (S) and young trees (T). For seedlings needles measured were the current year's second flush and for trees needles measured were the current year's first flush.

\begin{tabular}{cccc}
\hline Age & Shade & $\mathbf{N}_{\mathbf{A}}\left(\mathbf{g ~ m}^{-\mathbf{2}}\right)$ & $\mathbf{N}_{\mathbf{W}} \mathbf{( \mathbf { m g ~ g } ^ { - \mathbf { 1 } } )}$ \\
\hline \multirow{3}{*}{$\mathrm{S}$} & $0 \%$ & $1.3 \pm 0.1$ & $26.9 \pm 0.4$ \\
& $50 \%$ & $0.9 \pm 0.1$ & $24.9 \pm 0.8$ \\
& $P>F$ & $<0.001$ & 0.110 \\
\hline \multirow{2}{*}{$\mathrm{T}$} & $0 \%$ & $0.6 \pm 0.1$ & $7.4 \pm 0.4$ \\
& $50 \%$ & $0.6 \pm 0.1$ & $7.5 \pm 0.6$ \\
\hline
\end{tabular}


Table 5. Mean ( $\pm \mathrm{SE}$ ) chlorophyll $a(\mathrm{Chl} a)$, chlorophyll $b(\mathrm{Chl} b)$, and total chlorophyll $\left(\mathrm{Chl}_{\text {Total }}\right)$ concentrations expressed on a leaf area or dry weight basis, the chlorophyll $a / b$ ratio $(\mathrm{Chl} a / b)$ and the percentage of total foliar nitrogen $(\mathrm{N})$ allocated to chlorophyll $\mathrm{N}$ (Chl N/Total N) measured in September 2010 in response to shade treatment in longleaf pine seedlings $(\mathrm{S})$ and young trees $(\mathrm{T})$. For seedlings needles measured were the current year's second flush and for trees needles measured were the current year's first flush.

\begin{tabular}{|c|c|c|c|c|c|c|c|c|c|}
\hline Age & Shade & $\begin{array}{c}\text { Chl } a \\
\left(\mathrm{mg} \mathrm{m}^{-2}\right)\end{array}$ & $\begin{array}{c}\text { Chl } a \\
\left(\mathrm{mg} \mathrm{g}^{-1}\right)\end{array}$ & $\begin{array}{c}\text { Chl b } \\
\left(\mathrm{mg} \mathrm{m}^{-2}\right)\end{array}$ & $\begin{array}{c}\text { Chl b } \\
\left(\mathrm{mg} \mathrm{g}^{-1}\right)\end{array}$ & $\begin{array}{c}\text { Chl }_{\text {Total }} \\
\left(\mathrm{mg} \mathrm{m}^{-2}\right)\end{array}$ & $\begin{array}{c}\mathrm{Chl}_{\text {Total }} \\
\left(\mathrm{mg} \mathrm{g}^{-1}\right)\end{array}$ & Chl $a / b$ & $\begin{array}{c}\text { Chl N/ } \\
\text { Total N } \\
(\%) \\
\end{array}$ \\
\hline \multirow{3}{*}{$\mathrm{S}$} & $0 \%$ & $190.5 \pm 22.4$ & $3.8 \pm 0.5$ & $106.9 \pm 13.5$ & $2.1 \pm 0.3$ & $297.4 \pm 35.0$ & $5.9 \pm 0.8$ & $1.9 \pm 0.1$ & $1.2 \pm 0.2$ \\
\hline & $50 \%$ & $188.8 \pm 15.7$ & $5.0 \pm 0.7$ & $110.9 \pm 13.1$ & $2.9 \pm 0.5$ & $299.7 \pm 28.5$ & $7.9 \pm 1.2$ & $1.8 \pm 0.1$ & $1.7 \pm 0.3$ \\
\hline & $P>F$ & 0.938 & 0.125 & 0.513 & 0.062 & 0.934 & 0.095 & 0.151 & 0.132 \\
\hline \multirow{3}{*}{$\mathrm{T}$} & $0 \%$ & $71.0 \pm 12.6$ & $0.94 \pm 0.2$ & $21.3 \pm 4.8$ & $0.28 \pm 0.1$ & $92.3 \pm 16.8$ & $1.2 \pm 0.2$ & $3.5 \pm 0.5$ & $0.9 \pm 0.2$ \\
\hline & $50 \%$ & $88.0 \pm 12.8$ & $1.28 \pm 0.1$ & $29.7 \pm 3.8$ & $0.43 \pm 0.1$ & $117.7 \pm 12.3$ & $1.7 \pm 0.2$ & $3.0 \pm 0.2$ & $1.2 \pm 0.1$ \\
\hline & $P>F$ & 0.174 & 0.031 & 0.088 & 0.029 & 0.137 & 0.027 & 0.199 & 0.051 \\
\hline
\end{tabular}

\subsection{Trees}

In the tree study, the $50 \%$ shade treatment did not significantly influence LMA in July, but in August LMA was reduced from $74 \mathrm{~g} \mathrm{~m}^{-2}$ in $0 \%$ shade to $64 \mathrm{~g} \mathrm{~m}^{-2}$ in $50 \%$ shade (Table 2). The response of $\mathrm{P}_{\text {net }}$ to increasing PAR was non-linear in the two shade treatments (Figure 2). In August the light saturation point was generally lower $\left(<500 \mu \mathrm{mol} \mathrm{m} \mathrm{m}^{-2}\right)$ in the $50 \%$ shade treatment compared to the $0 \%$ shade treatment (approximately $700 \mu \mathrm{mol} \mathrm{m}^{-2} \mathrm{~s}^{-1}$ ). In July and August, $\mathrm{A}_{\max }$ was not significantly influenced by shading and average $A_{\max }$ was $4.0 \mu \mathrm{mol} \mathrm{m} \mathrm{m}^{-2} \mathrm{~s}^{-1}$ (Table 2). Shading reduced $g_{s m a x}$ in August. No significant effects of shade treatment on $R_{D}, A_{\text {max }}: R_{D}$, the LCP and $\Phi$ were observed either month (Table 3). Significant treatment effects on leaf water potential were observed only in August when shading increased $\Psi_{\mathrm{MD}}$ and $\Psi_{\mathrm{PD}}$ (Table 2).

Shading treatment had no significant effect on $\mathrm{N}_{\mathrm{W}}$ or $\mathrm{N}_{\mathrm{A}}$, and $\mathrm{N}_{\mathrm{W}}$ was on average $7.4 \mathrm{mg} \mathrm{g}^{-1}$ (Table 4). Chlorophyll $b$ expressed on a leaf area basis and chlorophyll $a$, chlorophyll $b$ and total chlorophyll on a leaf dry weight basis and the ratio of chlorophyll N/total $\mathrm{N}$ were increased by the $50 \%$ shade treatment (Table 5).

\section{Discussion}

Shade-intolerant species are often assumed to be less plastic in response to varying light environments than shade-tolerant species, but in an extensive analyses of LMA response to light, Poorter et al. [29] determined that species classified as shade intolerant had higher plasticity in light response than shade tolerant species. Likewise, in some cases plasticity of leaf anatomical and physiological traits to light may not be related to shade tolerance rankings [30]. Leaf mass per unit area has been used as a measure of foliar plasticity to light environment, and lower LMA is a common response to shaded environments, particularly in seedlings [31]. The ability to reduce LMA at low light has been shown to correlate with seedling survival [32]. The reduction in LMA from shading can be described as $\mathrm{LMA}_{\text {sun }} / \mathrm{LMA}_{\text {shade }}$ [33] and the ratio in seedlings was 1.20 in July and 1.30 in August. 
Jose et al. [34] found a similar ratio of 1.20 in one-year-old longleaf pine seedlings grown in a $60 \%$ shade treatment, and Groninger et al. [34] reported a similar ratio of 1.36 in loblolly pine (Pinus taeda L.) seedlings grown under a 79\% reduction in ambient PAR. Both the first flush and second flush of seedlings demonstrated lower LMA with shading even though initial growth of the first flush began outside the shade treatments. In foliage that develops in high light, LMA can adapt to shading within days as a result of breakdown of proteins, starch and hemicellulose and reduced leaf density [29], which is possibly the case for the first flush needles in seedlings. In trees, LMA was reduced by shading only in foliage that developed fully in shade and $\mathrm{LMA}_{\text {sun }} / \mathrm{LMA}_{\text {shade }}$ was 1.16 . Niinemets et al. [35] observed a significant relationship between LMA and canopy light environment in 16-year-old longleaf pine trees ranging in height from 7-9 $\mathrm{m}$ and reported values of LMA ranging from $90-110 \mathrm{~g} \mathrm{~m}^{-2}$. Despite the ranking of longleaf pine as more shade intolerant than other southern conifers, they observed that LMA of longleaf pine was as plastic to light environment as LMA of loblolly pine and Virginia pine (Pinus virginiana Mill.) [35].

In conifers, lower LMA in low light environments is associated with thinner needles and a smaller volume to total leaf area ratio [34], less investment in photosynthetic enzymes, and lower metabolic costs relative to higher LMA in high light environments [36,37]. If reduced LMA in low light is not accompanied by physiological changes such as reductions in $\mathrm{R}_{\mathrm{D}}$ and increases in chlorophyll content or $\Phi[38,39]$, then low LMA may be a symptom of growth in shade rather than an indicator of shade acclimation [34]. In both seedlings and trees, no significant reduction in $A_{\max }$ or $\mathrm{g}_{\text {smax }}$ or increase in $\Phi$ with shading was observed. The range in $\Phi$ we observed in longleaf pine is similar to the range of 0.017 to $0.031 \mu \mathrm{mol} \mathrm{CO}_{2} \mu \mathrm{mol}$ photon ${ }^{-1}$ reported for four-year-old loblolly pine [40]. Similar to our results, no change in $\Phi$ or $A_{\max }$ with shading was reported for loblolly pine seedlings [34,41]. Lack of a shading effect on $\Phi$ has also been observed in more shade tolerant tree species such as Acer rubrum L., Fagus grandifolia Ehrh., Quercus alba L., and Quercus rubra L. [34,41,42]. Shaded longleaf pine seedlings did demonstrate a lower LCP, decreased $R_{D}$ and increased $A_{\text {max }}: R_{D}$. The light in open-canopy longleaf pine forests has been described as a matrix of sunlit understory with shade interruptions that change on a daily and seasonal basis [8]. The ability to maintain photosynthesis and take advantage of higher light periods and sunflecks while reducing respirational costs in low light periods may enhance seedling survival in partial shade and explain, in part, the ability of longleaf pine to persist in the grass stage.

No changes in the LCP, $\Phi, \mathrm{R}_{\mathrm{D}}$ or $\mathrm{A}_{\text {max }}: \mathrm{R}_{\mathrm{D}}$ with shading were detected in trees. However, acclimation to low light can also occur through changes in the relative investment of $\mathrm{N}$ between photosynthetic components with re-allocation of $\mathrm{N}$ from soluble proteins into pigment-protein complexes reflected by increases in chlorophyll per unit leaf dry mass [36,43]. Chlorophyll per unit leaf dry mass is usually more responsive to light gradients than chlorophyll expressed on a leaf area basis [36], and lower LMA in shaded seedlings and trees was associated with increases in chlorophyll when expressed on a leaf dry weight basis. Adaptation to shading can occur through an increase in light harvesting chlorophyll-protein complexes which contain the majority of chlorophyll $b$ [44]. Young trees exhibited increases in chlorophyll $a$, chlorophyll $b$ and total chlorophyll and seedlings showed increases in chlorophyll $b$ and total chlorophyll. In addition, trees invested more total foliar $\mathrm{N}$ in chlorophyll $\mathrm{N}$ in response to shading. 
Low $\mathrm{N}$ availability is typical of longleaf pine habitats [45] and average $\mathrm{N}_{\mathrm{W}}$ ranged from 7.4 to $7.5 \mathrm{mg} \mathrm{g}^{-1}$ in trees. The sufficiency level for $\mathrm{N}_{\mathrm{W}}$ in longleaf pine suggested by Blevins et al. [46] is $9.5 \mathrm{mg} \mathrm{g}^{-1}$, but $\mathrm{N}_{\mathrm{W}}$ in young longleaf pine trees can commonly range from $6-9 \mathrm{mg} \mathrm{g}^{-1}$ on well-drained sandy soils [47]. In contrast, seedlings exhibited higher foliar $\mathrm{N}$ due to fertilization and the average $\mathrm{N}_{\mathrm{W}}$ of $25.9 \mathrm{mg} \mathrm{g}^{-1}$ was within the range of $22-28 \mathrm{mg} \mathrm{g}^{-1}$ for fertilized container-grown longleaf pine [48], and $25 \mathrm{mg} \mathrm{g}^{-1}$ is considered the upper end of optimal ranges for conifer seedlings [49]. Nutrient loading has been suggested as a mechanism to increase cold hardiness, stem and root biomass, and survival on outplanting sites in conifer seedlings including longleaf pine [48]. Therefore seedling $\mathrm{N}_{\mathrm{W}}$ was within the range for container-grown longleaf pine seedlings. While $\mathrm{N}_{\mathrm{W}}$ varied greatly between seedlings and trees, the evidence for dependence of light acclimation on nutrient availability is mixed. Portsmuth and Niinemets [50] hypothesized that plasticity in response to light would increase with increasing nutrient availability in tree seedlings, but found little nutrient dependent enhancement of plasticity in shade intolerant species. Low $\mathrm{N}_{\mathrm{W}}$ could reduce the relative investment of available $\mathrm{N}$ in Rubisco and photosynthetic electron transport that would affect $A_{\max }[51,52]$. However, no interactive effects of shading treatment and $\mathrm{N}$ fertilization on LMA and $\mathrm{P}_{\text {net }}$ of longleaf pine seedlings grown in a greenhouse were observed by Jose et al. [33], although $\mathrm{N}_{\mathrm{W}}$ increased significantly in response to fertilization. Likewise, no interactions between shading and fertilization were reported for $\mathrm{P}_{\text {net }}$ and chlorophyll content in loblolly pine trees [27]. In Pinus strobus L. seedlings grown in a greenhouse, Fownes and Harington [53] found that $\mathrm{N}$ fertilization increased $\mathrm{N}_{\mathrm{W}}$ and low light increased LMA but light and $\mathrm{N}$ treatment did not affect $\mathrm{A}_{\max }$ and no interaction between $\mathrm{N}$ and shade treatment was observed for $\mathrm{N}_{\mathrm{W}}$, LMA and $\mathrm{A}_{\max }$.

Pecot et al. [15] described two theories concerning mechanisms controlling longleaf pine seedling success in uneven aged systems. The first is that belowground competitive interactions between juvenile and mature trees rather than light limitations are most important in seedling establishment and larger gaps of up to 2 ha that increase the border distance between seedlings and mature trees are needed to reduce competition for nutrients and water [54]. However, larger gaps reduce pine litter fuel and increase hardwood release [55]. The second theory proposes that seedling growth is mainly light limited but smaller gaps provide sufficient light (35\% to $60 \%$ gap fraction) for establishment of advanced regeneration [17]. The light environment in gaps as small as 0.1 ha has been shown to support longleaf pine seedling growth [8]. Plasticity to light in leaf physiological and morphological traits observed in seedlings and young trees suggests that young longleaf pine is not extremely shade intolerant as previously classified. A degree of shade acclimation may explain reports of higher than expected growth rates in seedlings in smaller gaps with less light availability [8]. Shade tolerance is an important consideration in determining plantation density and, in natural regeneration, gap sizes and shapes. For example, lower planting densities are recommended for longleaf pine plantations relative to the other southern conifers based on intolerance of competition for light and other resources [4]. Gagnon et al. [55] recommended group selection silviculture in longleaf pine management largely based on the assumed shade-intolerant nature of longleaf pine. Manipulation of gap shape to provide partial shade may enhance survival and growth of seedlings on drought prone sites in species that can tolerate a degree of shading [7]. Seedlings were grown in pots and subjected to shade treatments in a greenhouse under optimal nutrient and water availability. Accordingly, seedling responses observed in this study may not be representative of seedlings naturally regenerated in gaps and application of these 
results may relate more to outplanted settings. However, these results do provide evidence that longleaf pine is not extremely shade intolerant and further studies on leaf plasticity to light in naturally regenerated seedlings are warranted. In addition to traits that enhance energy capture and carbon gain in low light [47], conservation of other resources, resistance to herbivory and physical stresses, and carbon storage and allocation patterns may also influence growth in shaded environments [56].

\section{Conclusions}

Longleaf pine seedlings and young trees demonstrated changes in leaf structure and in leaf physiological traits that support the hypothesis that young longleaf pine can express a degree of leaf phenotypic plasticity to light. These results have implications for management of longleaf pine, such as in determining planting density, the optimal size of canopy openings for artificially regenerated seedlings planted in gaps or in underplantings and for release of young cohorts in the understory. If longleaf pine can express phenotypic plasticity to light, then higher densities, smaller gap sizes and single tree selection approaches may provide sufficient light for growth of young longleaf pine while maintaining fuels needed for frequent prescribed fire and reducing the need for mechanical control of hardwoods [15].

\section{Acknowledgments}

This project was supported by the Center for Longleaf Pine Ecosystems at Auburn University. The authors wish to thank Robin Governo for assistance in the chlorophyll analysis and Wayne Bell at International Forest Company for providing the seedlings.

\section{Conflict of Interest}

The authors declare no conflict of interest.

\section{References}

1. Brockway, D.G.; Lewis, C.E. Long-term effects of dormant-season prescribed fire in plant community diversity, structure and productivity in a longleaf pine wiregrass ecosystem. For. Ecol. Manag. 1997, 96, 167-183.

2. Gilliam, F.S.; Platt, W.J. Effects of long-term fire exclusion on tree species composition and stand structure in an old-growth Pinus palustris (longleaf pine) forest. Plant Ecol. 1999, 140, 15-26.

3. Baldocchi, D.D.; Collineau, S. The physical nature of solar radiation in heterogeneous canopies: Spatial and temporal attributes. In Exploitation of Environmental Heterogeneity by Plants, Ecophysiological Processes Above and Below Ground; Caldwell, M.M., Pearcy, R.W., Eds.; Academic Press: London, UK, 1994; pp. 21-71.

4. Brockway, D.G.; Outcalt, K.W.; Boyer, W.D. Longleaf pine regeneration ecology and methods. In The Longleaf Pine Ecosystem, Ecology, Silviculture and Restoration; Jose, S., Jokela, E.J., Miller, D.L., Eds.; Springer: New York, NY, USA, 2006; pp. 95-134.

5. Baker, F.S. A revised shade tolerance table. J. For. 1949, 47, 179-181. 
6. Brockway, D.G.; Outcalt, K.W. Gap-phase regeneration in longleaf pine-Wiregrass ecosystems. For. Ecol. Manag. 1998, 106, 125-139.

7. Rodriguez-Trejo, D.A.; Duryea, M.L.; White, T.L.; English, J.R.; McGuire, J. Artificially regenerating longleaf pine in canopy gaps: Initial survival and growth during a year of drought. For. Ecol. Manag. 2003, 180, 25-36.

8. McGuire, J.P.; Mitchell, R.J.; Moser, E.B.; Pecot, S.D.; Gjerstad, D.H.; Hedman, C.W. Gaps in a gappy forest: Plant resources, longleaf pine regeneration, and understory response to tree removal in longleaf pine savannas. Can. J. For. Res. 2001, 31, 765-778.

9. Bhuta, A.A.; Kenneday, R.L.M.; Copenheaver, C.A.; Sheridan, P.M.; Campbell, J.B. Boundary-line patterns to determine disturbance history of remnant longleaf pine (Pinus palustris P. Mill.) in mixed forests of southeastern Virginia. J. Torrey Bot. Soc. 2008, 135, 516-529.

10. Keeley, J.E.; Zedler, P.H. Evolution of life histories in Pinus. In Ecology and Biogeography of Pinus; Richardson, D.M., Ed.; Cambridge University Press: Cambridge, UK, 1998; pp. 219-250.

11. Wahlenberg, W.G. Longleaf Pine: Its Use, Ecology, Regeneration, Protection, Growth, and Management; Charles Lathrop Pack Forestry Foundation: Washington, DC, USA, 1946.

12. Platt, E.J.; Evans, G.W.; Rathbun, S.L. The population dynamics of a long-lived conifer (Pinus palustris). Am. Nat. 1998, 131, 491-525.

13. Boyer, W.D. Pinus palustris Mill. longleaf pine. In Silvics of North America, Conifers; Burns, R.M., Honkala, B.H., Eds.; U.S. Department of Agriculture, Forest Service: Washington, DC, USA, 1990; Volume 1, pp. 405-412.

14. Pessin, L.J. Annual ring formation in Pinus palustris seedlings. Am. J. Bot. 1934, 21, 599-601.

15. Pecot, S.D.; Mitchell, R.J.; Palik, B.J.; Moser, E.B.; Hiers, J.K. Competitive responses of seedlings and understory plants in longleaf pine woodlands: Separating canopy influences above and below ground. Can. J. For. Res. 2007, 37, 634-648.

16. Harlow, W.H.; Harrar, E.S.; White, F.M. Textbook of Dendrology; McGraw-Hill Co.: New York, NY, USA, 1979; pp. 87-90.

17. Battaglia, M.A.; Mitchell, R.J.; Mou, P.P.; Pecot, S.D. Light transmittance estimates in a longleaf pine woodland. For. Sci. 2003, 49, 752-762.

18. Givnish, T.J. Adaptation to sun and shade: A whole plant perspective. Funct. Plant Biol. 1998, 15, 63-92.

19. Cregg, B.M.; Teskey, R.O.; Dougherty, P.M. Effect of shade stress on growth, morphology and carbon dynamics of loblolly pine branches. Trees 1993, 7, 208-213.

20. Henriksson, J. Differential shading of branches or whole trees: Survival, growth and reproduction. Oecologia 2001, 126, 482-486.

21. Lacointe, A.; Deleens, E.; Ameglio, T.; Saint-Joanis, B.; Lelarge, C.; Vandame, M.; Song, G.C.; Daudet, F.A. Testing the branch autonomy theory: $\mathrm{A}{ }^{13} \mathrm{C} /{ }^{14} \mathrm{C}$ double-labeling experiment on differentially shaded branches. Plant Cell Environ. 2004, 27, 1159-1168.

22. Brooks, J.R.; Shulte, P.J.; Bond, B.J.; Coulombe, R.; Domec, J.C.; Hinkley, T.M.; McDowell, N.; Phillips, N. Does foliage on the same branch compete for the same water? Experiments on Douglas-fir trees. Trees 2003, 17, 101-108. 
23. Hanson, P.J.; McRoberts, R.E; Isebrands, J.G.; Dixon, R.K. An optimal strategy for determining $\mathrm{CO}_{2}$ exchange range rate as a function of photosynthetic photon flux density. Photosynthetica 1987, 21, 98-101.

24. Samuelson, L.J.; Seiler, J.R.; Feret, P.P. Gas exchange and canopy structure of 9-year-old loblolly pine, pitch pine and pitch x loblolly hybrids. Trees 1992, 6, 28-31.

25. Minocha, R.; Martinez, G.; Lyons, B.; Long, S. Development of a standardized methodology for quantifying total chlorophyll and carotenoids from foliage of hardwood and conifer tree species. Can. J. For. Res. 2009, 39, 849-861.

26. Lichtenthaler, J.K. Chlorophylls and carotenoids: Pigments of photosynthetic biomembranes. Methods Enzymol. 1987, 148, 350-382.

27. Zhang, S.; Hennesssey, T.C.; Heinemann, R.A. Acclimation of loblolly pine (Pinus taeda) foliage to light intensity as related to leaf nitrogen availability. Can. J. For. Res. 1997, 27, 1032-1040.

28. Landhäusser, S.M.; Lieffers, V.J. Photosynthesis and carbon allocation of six boreal species grown in understory and open conditions. Tree Physiol. 2001, 21, 243-250.

29. Poorter, H.; Niinemets, Ü.; Poorter, L.; Wright, I.J.; Villar, R. Causes and consequences of variation in leaf mass (LMA): A meta-analysis. New Phytol. 2009, 182, 565-588.

30. Wyka, T.; Robakowski, P.; Zytkowiak, R. Acclimation of leaves to contrasting irradiance in juvenile trees differing in shade tolerance. Tree Physiol. 2007, 27, 1293-1306.

31. Greenwood, M.S.; Day, M.E.; Berlyn, G.P. Regulation of foliar plasticity in conifers: Developmental and environmental factors. J. Sustain. For. 2009, 28, 48-62.

32. Funk, J.L.; McDaniel, S. Altering light availability to restore invaded forest: The predictive role of plant traits. Restor. Ecol. 2010, 18, 865-872.

33. Jose, S.; Merritt, S.; Ramsey, C.L. Growth, nutrition, photosynthesis and transpiration responses of longleaf pine seedlings to light, water and nitrogen. For. Ecol. Manage. 2003, 180, 335-344.

34. Groninger, J.W.; Seiler, J.R.; Peterson, J.A.; Kreh, R.E. Growth and photosynthetic responses of four Virginia Piedmont trees species to shade. Tree Physiol. 1996, 16, 773-778.

35. Niinemets, Ü.; Ellsworth, D.S.; Lukjanova, A.; Tobias, M. Dependence of needle architecture and chemical composition on canopy light availability in three North American Pinus species with contrasting needle length. Tree Physiol. 2002, 22, 747-761.

36. Niinemets, Ü. A review of light interception in plant stands from leaf to canopy in different plant functional types and in species with varying shade tolerance. Ecol. Res. 2010, 25, 693-714.

37. Saldaña, A.; Gianoli, E.; Lusk, C.H. Ecophysiological responses to light availability and three Blechem species (Pteridophyta, Blechnaceae) of different ecological breadth. Oecologia 2005, 145, 252-257.

38. Walters, M.B.; Field, C.B. Photosynthetic light acclimation in two rainforest piper species with different ecological amplitudes. Oecologia 1987, 72, 449-456.

39. Larcher, W. Physiological Plant Ecology; Springer: New York, NY, USA, 1996.

40. Samuelson, L.; Stokes, T.; Cooksey, T.; McLemore, P., III. Production efficiency of loblolly pine and sweetgum in response to four years of intensive management. Tree Physiol. 2001, 21, 369-376.

41. Teskey, R.O.; Shrestha, R.B. A relationship between carbon dioxide, photosynthetic efficiency and shade tolerance. Physiol. Plant 1985, 63, 126-132. 
42. Rebbeck, J.; Scherzer, A.; Gottschalk, K. Do chestnut, northern red, and white oak germinant seedlings respond similarly to light treatments? II. Gas exchange and chlorophyll responses. Can. J. For. Res. 2012, 42, 1025-1037.

43. Evans, J.R.; Poorter, J.H. Photosynthetic acclimation of plants to growth irradiance: The relative importance of specific leaf area and nitrogen partitioning in maximizing carbon gain. Plant Cell Environ. 2001, 24, 755-767.

44. Terashima, I.; Hikosaka, K. Comparative ecophysiology of leaf and canopy photosynthesis. Plant Cell Environ. 1995, 18, 111-1128.

45. Christensen, N.L. Fire and soil-plant nutrient relations in a pine-wiregrass savanna on the coastal plain of North Carolina. Oecologia 1977, 31, 27-44.

46. Blevins, D.; Allen, H.L.; Colbert, S.; Gardner, W. Nutrition Management for Longleaf Pinestraw; Woodland Owner Notes-30; North Carolina (State University) Cooperative Extension Service: Raleigh, NC, USA, 1996.

47. Samuelson, L.J.; McLemore, P.C., III.; Somers, G.L. Relationship between foliar $\delta^{13} \mathrm{C}$ and hydraulic pathway length in Pinus palustris. For. Sci. 2003, 49, 790-798.

48. Jackson, D.P.; Dumroese, R.K.; Barnett, J.P. Nursery response of container Pinus palustris seedlings to nitrogen supply and subsequent effects on outplanting performance. For. Ecol. Manage. 2012, 265, 1-12.

49. Landis, T.D.; Tinus, R.W.; McDonald, S.E.; Barnett, J.P. Seedling nutrition and irrigation. In The Container Tree Nursery Manual; Landis, T.D., Tinus, R.W., McDonald, S.E., Barnett, J.P., Eds; U.S. Department of Agriculture, Forest Service: Washington, DC, USA, 1989; Volume 4, pp. 1-67.

50. Portsmuth, A.; Niinemets, Ü. Structural and physiological plasticity in response to light and nutrients in five temperate deciduous woody species of contrasting shade tolerance. Funct. Ecol. 2007, 21, 61-77.

51. Kitajima, K.; Hogan, K.P. Increases of chlorophyll $a / b$ ratios during acclimation of tropical woody seedlings to nitrogen limitation and high light. Plant Cell Environ. 2003, 26, 857-865.

52. Terashima, I.; Hanba, Y.T.; Tazoe, Y.; Vyas, P.; Yano, S. Irradiance and phenotype: Comparative eco-development of sun and shade leaves in relation to photosynthetic $\mathrm{CO}_{2}$ diffusion. J. Exp. Bot. 2006, 57, 343-354.

53. Fownes, J.H.; Harrington, R.A. Seedling response to gaps; separating effects of light and nitrogen. For. Ecol. Manage. 2004, 203, 297-310.

54. Gulden, J.M. Uneven-aged silviculture of longleaf pine. In The Longleaf Pine Ecosystem, Ecology, Silviculture and Restoration; Jose, S., Jokela, E.J., Miller, D.L., Eds.; Springer: New York, NY, USA, 2006; pp. 217-241.

55. Gagnon, J.L.; Jokela, E.J.; Moser, W.K.; Huber, D.A. Dynamics of artificial regeneration in gaps within a longleaf pine flatwoods ecosystem. For. Ecol. Manag. 2003, 172, 133-144.

56. Lusk, C.H. Leaf area and growth of juvenile temperate evergreens in low light, species of contrasting shade tolerance change rank during ontogeny. Funct. Ecol. 2004, 18, 820-828.

(C) 2012 by the authors; licensee MDPI, Basel, Switzerland. This article is an open access article distributed under the terms and conditions of the Creative Commons Attribution license (http://creativecommons.org/licenses/by/3.0/). 